\title{
SOCIAL EFFICIENCY AS A MEASURE OF SOCIAL ACTIVITIES
}

\author{
Venelin Terziev \\ Academician of the Russian Academy of Natural History, Moscow, Russia, \\ Prof. D.Sc. (Ec.), D.Sc. (National Security), D.Sc. (Social Activities), Ph.D., National Military \\ University, Veliko Tarnovo, Bulgaria; University of Rousse, Rousse, Bulgaria, terziev@skmat.com
}

\begin{abstract}
Speaking of efficiency as a key concept for any socio-economic activity, the focus is traditionally on economic efficiency, expressed in the "costs-effects (benefits)" correlation. Since every social activity is carried out with even more limited resources, the approach should be as to an economic activity. Moreover, "any purposeful activity in which the limited resources are allocated and combined between alternatives, as maximizing of the effect or cost minimization is possible" is considered as such. The ratio between costs and benefits of a resource or combination of resources to achieve a set, per-determined objective and on this basis the rationalization of the management decisions come to the fore. In this sense, the "cost-effect" correlation can be used as a "tool for planning; instrument for decision-making and environment for historical documentation of the decisions made".
\end{abstract}

Keywords: social efficiency, social activities, social progress, social programming, social development.

\section{INTRODUCTION}

Speaking of efficiency as a key concept for any socio-economic activity, the focus is traditionally on economic efficiency, expressed in the "costs-effects (benefits)" correlation. Since every social activity is carried out with even more limited resources, the approach should be as to an economic activity. Moreover, any purposeful activity in which the limited resources are allocated and combined between alternatives, as maximizing of the effect or cost minimization is possible" is considered as such. The ratio between costs and benefits of a resource or combination of resources to achieve a set, per-determined objective and on this basis the rationalization of the management decisions come to the fore. In this sense, the "cost-effect" correlation can be used as a "tool for planning; instrument for decision-making and environment for historical documentation of the decisions made".

This fundamental principle, characterizing the economic efficiency is one of the sides to study the effectiveness of the activity. However, any activity is social by its nature and determines the need of measurability of the social effects. On this basis, the so-called social efficiency is more and more discussed in recent years. Unlike the economic efficiency, the social efficiency does not have so direct character, it is rather a more complex category and is difficult to express in one dimension.

Another approach where efficiency is measured at the level of protection of the balanced interests of the state and society is also worth attention. The work of the state apparatus may be recognized as effective 
only in case if it successfully solves the problem for optimal protection of the interests of the population, social groups and every person. In this dual task, the most important part is the concept of efficiency of the state apparatus. According to this approach, the efficiency is expressed in expanding the opportunities for active civic life of every citizen, the society and the efficiency of the state. It is determined by a wellfunctioning activity system of the state organs, their ability to legally implement state interests and implement state policy on social and community development.

Another point of view that connects the efficiency of governmental activities is the presence or absence of optimal paradigm for administrative and political management. It comes to opposing the traditional technocratic paradigm of political government to the new participative one (Georgiev, 2016; Georgiev, 2017a).

\section{SOCIAL EFFICIENCY AS A MEASURE OF SOCIAL ACTIVITIES}

Speaking of efficiency as a key concept for any socio-economic activity, the focus is traditionally on economic efficiency, expressed in the "costs-effects (benefits)" correlation. Since every social activity is carried out with even more limited resources, the approach should be as to an economic activity. Moreover, „any purposeful activity in which the limited resources are allocated and combined between alternatives, as maximizing of the effect or cost minimization is possible" is considered as such. The ratio between costs and benefits of a resource or combination of resources to achieve a set, per-determined objective and on this basis the rationalization of the management decisions come to the fore. In this sense, the "cost-effect" correlation can be used as a "tool for planning; instrument for decision-making and environment for historical documentation of the decisions made".

This fundamental principle, characterizing the economic efficiency is one of the sides to study the effectiveness of the activity. However, any activity is social by its nature and determines the need of measurability of the social effects. On this basis, the so-called social efficiency is more and more discussed in recent years. Unlike the economic efficiency, the social efficiency does not have so direct character, it is rather a more complex category and is difficult to express in one dimension.

Another approach where efficiency is measured at the level of protection of the balanced interests of the state and society is also worth attention. The work of the state apparatus may be recognized as effective only in case if it successfully solves the problem for optimal protection of the interests of the population, social groups and every person. In this dual task, the most important part is the concept of efficiency of the state apparatus. According to this approach, the efficiency is expressed in expanding the opportunities for active civic life of every citizen, the society and the efficiency of the state. It is determined by a wellfunctioning activity system of the state organs, their ability to legally implement state interests and implement state policy on social and community development.

Another point of view that connects the efficiency of governmental activities is the presence or absence of optimal paradigm for administrative and political management. It comes to opposing the traditional technocratic paradigm of political government to the new participative one (Terziev, Kanev, 2019; Terziev, 2019a-k; Terziev, 2018-d).

\section{SOCIAL EFFICIENCY AS A MEASURE OF SOCIAL ACTIVITIES}

In general, the author directly link the efficiency of the governmental activities with the presence in it of bureaucracy that is actually serving society. And this is the bureaucracy which: is under real control of society; expresses the interests of social progress; is minimum in its quantitative and qualitative parameters. This statement is based on an inherent contradiction in the bureaucracy between broad public objectives for which it has been created and its close corporate interests with the tendency to dominate.

According to some authors, efficiency criteria of social management consist of the following:

- The compliance of the directions, the content and performance of the management structures and of these parameters, which are determined by the functions and status;

- The legality of the decisions and actions corresponding to the management structures and the users (recipients, beneficiaries);

- The reality of the impact of the management on the status and development of the managed objects;

- The depth of reporting and presentation in management decisions and actions on specific and complex needs, interests and goals of people;

- The nature and volume of the direct and „reverse” connections with beneficiaries, or in other words in the 
democracy of the activities;

- The extent of authority of the decisions and actions of the management structures;

- The credibility and relevance of the information conveyed to the management structures and beneficiaries.

- Impact of the management activity in relation to the external environment.

Any action, any social event or quality, including social efficiency, is characterized by quantitative and qualitative aspects. Even though these two aspects of the object exist in an inseparable unity and interconnection, they are still different characteristics of the surrounding social reality. The scientific literature has adopted the term "criterion" to indicate the qualitative aspect of the result (effect) and the term "efficiency indicator" to denote the quantitative aspect.

Other research suggests a slightly different interpretation of the term „criterion of social efficiency”, considering it in terms of the relationship between the qualitative and quantitative determination of the studied and assessed object. In respect to the quantitative aspect, the criterion appears as a method, an instrument, a reference measure for moving towards the desired outcome, and in respect to the quantitative aspect - as an opportunity to separate the "positive aspects, forms of this movement in space and time".

However, given all the differences in the understanding of the term „criterion” in the designated approaches, there is a semantic unity. Moreover, their synthesis gives us new, deeper understanding of the social nature of social efficiency. In this way, "the efficiency indicator" (quantitative criterion), fixes the objectified and integral, mainly quantitatively expresses (e.g. in terms of the natural volume of social benefits and the time interval to secure them) the assessment of the achievements by the social system of each rank. "The efficiency criterion" (quality criterion) in a larger degree focuses on the study of the internal mechanisms for achieving a given result, including the degree of limitation and the so called activation of the human factor, as a condition for self-development, efficient activity, social price of the achieved, the extent of its limitation etc. This distinction is essential and important for the development of the system for the assessment of social work.

No matter what is the quantity of efficiency of the operating and the developing social system, it is always the result of the actions of all the factors of the system as a whole, presented as an integrative productivity. Moreover, it is important to emphasize that no matter how extraordinary efficient the activity of the separate factors in the social system, its efficiency can be secured only by the corresponding quality of systematic social interaction. It comes as its irrevocable organic property and serves as a general algorithm and a universal motivational mechanism for the activity of all the factors in the system.

The relationship between economic and social efficiency has a complex character. At the basis of the growth of economic efficiency, a methodological principle is usually placed according to which the implementation of the social program is in it self bound to become a catalyst for effective economic development. The funds spent by society to meet social needs, are returned in the end as evident increase of the social and labor efficiency. In this system, the realization of social control is ultimately one of the subordinate factors for achieving economic efficiency.

The effort to treat in a similar way the impact of the economic factor for achieving integrated social performance, will inevitably suffer from a simplistic approach. It has already been recognized as obvious that at a certain essence of social efficiency, the classic criterion (the ratio between cost and income) is clearly insufficient. We need a different approach, by means of which we could assess the effectiveness of one social activity or another. The level for achieving social efficiency, which is determined by the position of the movement to a socially significant strategic objective that is comprehensively revealed as a state of the most complete realization of the needs of the individual and self-realization of their essential strengths, in other words their personality. The prosperity of the individual, as a supreme value for society, becomes an end in itself for social development. Therefore, the prospective objective of any development usually comes as a requirement to determine the complete prosperity and free all-round development of all members of society, which is realized primarily in the creation of humane living and working conditions.

It is also necessary to make a number of important methodological and logical specifications. The idea of social efficiency as productivity, evaluated from the perspective of approaching the socially significant objective, should be related to the changes corresponding to the general line of the progressive development of the social system, i.e. with its gradual transition from less to more perfect existence. We can note that before we compare any achieved social result with the costs, it is necessary to clarify the significance of the mere fact of reaching this result, especially in terms of its compliance with the objectives of social development. It is also important to take into account the time interval required to achieve the set goal. 
Considering the problem of social efficiency, depending on the notions of social progress and its ideal, creates additional difficulties. In those cases, where the social impact is difficult to quantify, the only reliable criterion for its evaluation can only be the degree of approaching the objective, to the realization of these values, which are set out in it. In a number of works, primarily the content of the notions of „social impact” and "social efficiency" has been considered. As a rule, the authors of publications agree that the social effect is a certain social result, a goal setting activity that has been conducted by economic decisions. Moreover, in one case it is perceived as "something related to human development", which "forms new features in the image of life and activity, both individual and collective, gives evidence of increasing social activity, contributing to a comprehensive personal development and the formation of a new type of worker". In another case, it is treated as „a result, meeting the goals of social development”. In a third case - as a "degree for improving the social and psychological or hygiene comfort of the individual". In the latest cases, it is not the social result as such that is taken in mind, but the efficiency, i.e. the ratio between the result and the objective, the initial and the subsequent state of social comfort .

The proposed definitions allow capturing the essential differences between the concepts of "social impact” and "social efficiency". In the first, the conclusion how to reach determined, qualitatively or quantitatively measurable results of social activity in their self-importance, is reflected. In the second case, there is a correlation of these results with the measure or degree of realization of the set goal or ideal of social development. This measure for assessment of the social impact serves in turn as an important indication for this qualitative side of social activity integrated into its system organization. Thanks to it, the very social efficiency is achieved. This inherent efficiency of the social activity- the constitutive qualitative characteristics, can be defined as a principle of social efficiency. It is directly related to the criteria for social efficiency as specific quality properties and determinants of meanings on the basis of which, as a kind of „zero points for rendering account", the social activity is assessed as effective or ineffective. Considering the features that distinguish the social efficiency from the outcome, it is related either to the goals or to the needs. It should be noted that "the most effective in other equal conditions will be an activity in which the goal to a maximum degree reflects the human needs". Along with that, the issue of the specific social outcomes (effects) of the management impact has not been raised, although it is presented in the given context as a very significant one. The fact is that the considering of the issue for assessment of the social efficiency and the content of this concept itself are inseparable from the specific analysis of both normatively or ideologically set goals for social development, and the needs (expectations, interests, ideals) of various social actors.

It seems that social efficiency cannot be considered within the categories of the abstract social prosperity or just as a movement of the social system to some generalized goal of social development. The social object, which is the object of management, which the concept of social efficiency refers to, is quite complicated in its structure. It covers the whole range of existing social and public relations. The social management goals themselves inevitably affect the "space” of these relations, including the social system (the society) in an entirety, the social groups (communities) and the separate individuals (persons). Based on this and the efficiency of the social management activities, it is necessary to think on the overall assessment for the development of all aspects and components of the social system.

It is obvious that the above examined correlation of the efficient social activity to the objectives of social progress indicates one of the important moments of social connection and interdependence between the general systematic, social-group and individual-personal dimensions of the social activity, of the complete and as a rule long lasting nature of its manifestation.

When discussing the issue of socio-economic efficiency of the targeted complex programs, it is found that "the main purpose of the statements and assessment of social efficiency within the program-target method is the basis of the received planning and management decisions." Considering the need to anticipate the social consequences of economic activities that are required to be reported in the overall evaluation of their efficiency, a number of authors note that in order to do that "sustainable or quantitative (although consecutive) dependencies between manufacturing and technical and social changes, between the characteristics of planned events and indicators reflecting the corresponding target norms", shall be revealed.

Some authors associate social efficiency of economy efficiency with the problem of efficiency. In economy and sociology, even the question of the legality of a concept like "social efficiency" (in contrast to the more or less clear economic maximum production at minimum costs) appears to be arguable. These scholars, who consider this concept as lawful, try to give it a more specific definition. In particular, the criterion of social efficiency is a way to solve topical social problems in minimum time and minimum costs for society. The presented definition has a debatable character, because the development of criteria for optimality in the social sphere would significantly move ahead the understanding of the criterion of social efficiency, no matter what the final wording of this concept would be. 
The formulation of the question for optimality of the social activity as an integral criterion for its performance is promising precisely because of the complexity of every social object, its dependence on a number of variables, but also on the presence of multi-vector internal systematic contradictions.

When defining the complex evaluation of the efficiency of social programs, it is appropriate to note the following (Terziev, Kanev, 2019; Terziev, 2019a-k; Terziev, 2018-d; Terziev, Georgiev, 2018e-f; Terziev, Arabska, 2014; Terziev, 2015-b; Terziev, Arabska, 2016a):

- The efficiency assessment of social programs should be considered in the midline of the quantitative and qualitative indicators: the quantitative indicator is expressed in the natural volume of social welfare, but also in material costs for obtaining them and qualitative indicator or criterion is reflected in the internal mechanisms for achieving a certain result, the quality of the organizational and managerial systems, the norms and values, the rules of law on which the activity in a given social system is considered effective or not;

- In the assessment of the programs, their economic and social efficiency should also be taken into account. The economic efficiency is evident in the fact that the implementation of the social program is in itself bound to become a catalyst for effective economic development. The funds, spent by society to meet social needs, shall be returned at the end in the form of increased social and labor activities;

- The level for achieving social efficiency is determined by the position of the movement to a socially significant goal that is comprehensively revealed as a state of the most complete realization of the needs of the individual and self-realization of their essential strengths, in other words their personality, which is realized above all in the creation of human living and development conditions.

\section{CONCLUSION}

In case of difficulty or eventual calculating of economic efficiency, the optimality in achieving social impact appears as a problem.

It should also be borne in mind that the results from the programs relate either to the objectives of the creators of the program, or to the needs of those to whom these programs are directed. In this case, efficiency is reached to a greater extent by these programs where the objectives of the managers and organizers of the program fully reflect the needs of the subjects of the program.

Due to the extreme complexity in reporting and evaluation of strategic and long-term consequences of the social measures within the broader social approach in determining the social efficiency, we examine the social efficiency of implemented state programs in close practical terms. And that means highest productivity in solving a specific social problem. Evaluating the efficiency of social programs in this is brought to the task of optimization of social management activities in the process of solving specific social programs by the program approach. That, more than ever, requires the definition of criteria for effectiveness of social programs and on this basis - the implementation of appropriate assessment methodologies (Terziev, Arabska, 2014; Terziev, 2015-b; Terziev, Arabska, 2016a).

\section{REFERENCE LIST}

Georgiev, Marin. (2016). Obshtestvenoto i ikonomichesko razvitie v konteksta na sotsialnite politiki. // Spisanie za nauka "Novo znanie“. Visshe Uchilishte po Agrobiznes i Razvitie na Regionite, 5, 2016, N 4, str. 26-41, ISSN 2367-4598 (Online), (Print) ISSN 1314-5703 (Георгиев, Марин. Общественото и икономическо развитие в контекста на социалните политики. // Списание за наука „Ново знание“. Висше училище по агробизнес и развитие на регионите, 5, 2016, N 4, стр. 26-41, ISSN 2367-4598 (Online), (Print) ISSN 1314-5703.

Georgiev, Marin. (2017). Sbalansirovannaya karta kak alyternativa malogo biznesa. // Innovatsionnie tehnologii v nauke novogo vrmeni, Sbornik statey Mezhdunarodnoy nauchno - prakticheskoy konferentsii 1 fevralya 2017 g., Ufa NITS AETERNA, Chasty 1, 2017, s. 43-49, ISBN 978-5-00109004-5, ISBN 978-5-00109-007-6 (Георгиев, Марин. Сбалансированная карта как альтернатива малого бизнеса. // Инновационніе технологии в науке нового врмени, Сборник статей Международной научно - практической конференции 1 февраля 2017 г., Уфра НИЦ АЭТЕРНА, Часть 1, 2017, с. 43-49, ISBN 978-5-00109-004-5, ISBN 978-5-00109-007-6).

Georgiev, Marin. (2017a). Impacts of active social programs on labor market. // Mezhdunarodnayy 
nauchnayy zhurnal „Innovatsionnaya nauka“. NITS Aeterna, N 02-1, 2017, pp. 139-143, ISSN 24106070 (Georgiev, Marin. Impacts of active social programs on labor market. // Международный научный журнал „Инновационная наука“. НИЦ Аэтерна, N 02-1, 2017, pp. 139-143, ISSN 24106070).

Terziev, V., Kanev, D. (2019). Modern developments in behavioral economics. // Smart Technologies and Innovations in Design for Control of Technological Processes and Objects: Economy and Production Proceeding of the International Science and Technology Conference „FarEastCon-2018” Volume 138, October 2-4, 2018, Vladivostok, Russian Federation, pp. 10-23, 2019, (Print) ISBN978-3-030-15576-6, (Online) ISBN978-3-030-15577-3.

Terziev, Venelin. (2019a). Provision of integrated employment and social assistance services in Bulgaria. // Smart Technologies and Innovations in Design for Control of Technological Processes and Objects: Economy and Production Proceeding of the International Science and Technology Conference „FarEastCon-2018” Volume 138, October 2-4, 2018, Vladivostok, Russian Federation, pp. 24-39, 2019, (Print) ISBN978-3-030-15576-6, (Online) ISBN978-3-030-15577-3.

Terziev, Venelin. (2019b). Problems of control in the social sphere. // INTCESS 2019- $6^{\text {th }}$ International Conference on Education and Social Sciences, 4-6 February, 2019, Dubai, International Organization Center of Academic Research, Istanbul, Turkey, pp. 577-593, ISBN: 978-605-82433-5-4.

Terziev, Venelin. (2019c). The criterion "competence" in the economic sector. // INTCESS 2019-6th International Conference on Education and Social Sciences, 4-6 February, 2019, Dubai, International Organization Center of Academic Research, Istanbul, Turkey, pp. 1241-1247, ISBN: 978-605-824335-4.

Terziev, Venelin. (2019d). Social policy and labor market development in Bulgarian transition period. // INTCESS 2019- $6^{\text {th }}$ International Conference on Education and Social Sciences, 4-6 February, 2019, Dubai, International Organization Center of Academic Research, Istanbul, Turkey, pp. 703-714, ISBN: 978-605-82433-5-4.

Terziev, Venelin. (2019e). Theoretical basis of development of labor market and social policy in the republic of Bulgaria. // INTCESS 2019- ${ }^{\text {th }}$ International Conference on Education and Social Sciences, 4-6 February, 2019, Dubai, International Organization Center of Academic Research, Istanbul, Turkey, pp. 715-726, ISBN: 978-605-82433-5-4.

Terziev, Venelin. (2019f). The problem of social efficiency- Indicators for social efficiency. // INTCESS 2019$6^{\text {th }}$ International Conference on Education and Social Sciences, 4-6 February, 2019, Dubai, International Organization Center of Academic Research, Istanbul, Turkey, pp. 669-678, ISBN: 978605-82433-5-4.

Terziev, Venelin. (2019g). Experiencing social policy development and efficiency measurment. // INTCESS 2019- $6^{\text {th }}$ International Conference on Education and Social Sciences, 4-6 February, 2019, Dubai, International Organization Center of Academic Research, Istanbul, Turkey, pp. 679-686, ISBN: 978605-82433-5-4.

Terziev, Venelin. (2019h). Efficiency and assessment of social technology. // INTCESS 2019- $6^{\text {th }}$ International Conference on Education and Social Sciences, 4-6 February, 2019, Dubai, International Organization Center of Academic Research, Istanbul, Turkey, pp. 687-694, ISBN: 978-605-82433-5-4.

Terziev, Venelin. (2019i). Conceptual framework of social adaptation. // INTCESS 2019- $6^{\text {th }}$ International Conference on Education and Social Sciences, 4-6 February, 2019, Dubai, International Organization Center of Academic Research, Istanbul, Turkey, pp. 494-503, ISBN: 978-605-82433-5-4.

Terziev, Venelin. (2019j). The dependence social adaptation- socialization. // INTCESS 2019- $6^{\text {th }}$ International Conference on Education and Social Sciences, 4-6 February, 2019, Dubai, International Organization Center of Academic Research, Istanbul, Turkey, pp. 478-485, ISBN: 978-605-82433-5-4.

Terziev, Venelin. (2019k). Social activity and human resources as social development factors. // INTCESS 2019- $6^{\text {th }}$ International Conference on Education and Social Sciences, 4-6 February, 2019, Dubai, International Organization Center of Academic Research, Istanbul, Turkey, pp. 546-553, ISBN: 978605-82433-5-4.

Terziev, Venelin. (2018). The active model of a social programme and its strategic advantage .// ADVED 2018- $4^{\text {th }}$ International Conference on Advances in Education and Social Sciences Abstracts \& Proceedings, 15-17 October 2018- Istanbul, Turkey, International Organization Center of Academic 
Research, www.ocerints.org, Istanbul, Turkey, 2018, pp. 189-203, ISBN: 978-605-82433-4-7.

Terziev, Venelin. (2018a). Active social programs development in Bulgaria: contemporary challenges and social management instruments. // ADVED 2018- $4^{\text {th }}$ International Conference on Advances in Education and Social Sciences Abstracts \& Proceedings, 15-17 October 2018- Istanbul, Turkey, International Organization Center of Academic Research, www.ocerints.org, Istanbul, Turkey, 2018, pp. 149-163, ISBN: 978-605-82433-4-7.

Terziev, Venelin. (2018b). Social assistance services and integrated employment in Bulgaria. // ADVED 2018- $4^{\text {th }}$ International Conference on Advances in Education and Social Sciences Abstracts \& Proceedings, 15-17 October 2018- Istanbul, Turkey, International Organization Center of Academic Research, www.ocerints.org, Istanbul, Turkey, 2018, pp. 164-177, ISBN: 978-605-82433-4-7.

Terziev, Venelin. (2018c). Impact of the labor market policies for ensuring employment. // ADVED 2018- $4^{\text {th }}$ International Conference on Advances in Education and Social Sciences Abstracts \& Proceedings, 1517 October 2018- Istanbul, Turkey, International Organization Center of Academic Research, www.ocerints.org, Istanbul, Turkey, 2018, pp. 178-188, ISBN: 978-605-82433-4-7.

Terziev, Venelin. (2018d). Importance of human resources to social development. // ADVED 2018- $4^{\text {th }}$ International Conference on Advances in Education and Social Sciences Abstracts \& Proceedings, 1517 October 2018- Istanbul, Turkey, International Organization Center of Academic Research, www.ocerints.org, Istanbul, Turkey, 2018, pp. 204-212, ISBN: 978-605-82433-4-7.

Terziev, V., Georgiev, M. (2018e). A strategic framework for the development of social entrepreneurship in Bulgaria. // Knowledge - International Journal, August 2018, Institute of Knowledge Management, Skopje, Macedonia, 25, 2018, N 1, pp. 23-34, ISSN 1857-923X (for e-version), ISSN 2545 - 4439 (for printed version).

Terziev, V., Georgiev, M. (2018f). Support for the development of social entrepreneurship in Bulgaria. // Knowledge - International Journal, September, 2018, Institute of Knowledge Management, Skopje, Macedonia, 26, 2018, N1, pp.57-74, ISSN 1857-923X (for e-version), ISSN 2545 - 4439 (for printed version).

Terziev, V., E., Arabska. (2014). Assessment of active social policies' impacts on labor market in the Republic of Bulgaria. Kolektivnaya monografiya "Sotsialyno-ekonomicheskie i pravovay razvitiya ekonomiki“, Ufa, Aeterna. Rossiya, 2014. ISBN 978-5-906769-97-8, str. 3-57 (Terziev, V., E. Arabska. (2014). Assessment of active social policies' impacts on labor market in the Republic of Bulgaria. Колективная монография „Социально-экономические и правовы развития экономики“, Уфа, Аэтерна. Россия, 2014. ISBN 978-5-906769-97-8, стр. 3-57).

Terziev, Venelin. (2015). Impact of active social policies and programs in the period of active economic transformations in Bulgaria, „East West” Association for Advanced Studies and Higher Education, Vienna, 2015, ISBN 78-3-903063-44-0, 434 p.

Terziev, Venelin. (2015a). Assessment of active social policies impact of social policies on transformation processes in bulgarian economy, Moscow, 2015, Publisher „Перо“, 110 p.

Terziev, Venelin. (2015b). Opportunities for improving the efficiency of the social adaptation of servicemen discharged from military service in Bulgaria:- Novosibirsk: Publisher CRNS, 2015. ISBN 978-5-00068402-3, $270 \mathrm{p}$.

Terziev, V., E., Arabska. (2016a). Effektivnoe vliyanie na raynok truda posredstvom uluchsheniya realizatsii sotsialynoy politiki. Novosibirsk: Izdatelystvo TSRNS, 2016. ISBN 978-5-00068-496-2, $312 \mathrm{str}$ (Терзиев, В., Е. Арабска. (2016а). Эфрфективное влияние на рынок труда посредством улучшения реализации социальной политики. Новосибирск: Издательство ЦРНС, 2016. ISBN 978-5-00068-496-2, 312 стр). 